\title{
Studi Pengelolaan Dana Desa untuk Pemberdayaan Masyarakat di Kabupaten Wonosobo
}

\author{
Affiliation: \\ Program Studi Akuntansi, Fakultas \\ Ekonomi dan Bisnis, Universitas \\ Muhammadiyah Yogyakarta, Indonesia \\ *Correspondence: \\ evy.rahman@umy.ac.id \\ This Article is Avalilable in: \\ https://journal.umy.ac.id/index.php/jat \\ i/article/view/12093
}

DOI:

https://doi.org/10.18196/jati.v4i2.120 93

\section{Citation:}

Ardiyani, A., Utami, E., Amanati, H., \& Yusuf, A. (2021). Studi Pengelolaan Dana Desa untuk Pemberdayaan Masyarakat di Kabupaten Wonosobo. Jati: Jurnal Akuntansi Terapan Indonesia, 4(2), 178-189.

\section{Article History}

Received:

22 July 2021

Reviewed:

26 Agustus 2021

Revised:

01 September 2021

Accepted:

30 September 2021

Topic Article:

Sector Public Accounting

\author{
Annisa Riva Ardiyani, Evy Rahman Utami*, Hilma Tsani Amanati, \\ Abdurrahman Maulana Yusuf
}

\section{Abstract:}

This study aims to analyze the village government's management of village funds to increase the empowerment of rural communities in the Wonosobo Regency. Several villages in Wonosobo Regency were selected based on the classification of the Building Village Index, including Krasak, Blederan, Kebrengan, and Derongisor. This study uses a qualitative method with a descriptive approach. Data collection techniques used are interviews, documentation, and observation. Interviews were conducted with informants from village officials and community representatives. Data analysis was carried out with data collection from interview transcriptions, direct observations, and documents. The study results indicate that the management of village funds carried out by the village government in Wonosobo Regency has paid attention to aspects of accountability and transparency. In addition, the use of funds is also right on target, prioritized for community empowerment. Overall, good management of village funds has increased empowerment and provided benefits to communities in various areas.

Keywords: Village Funds, Accountability, Transparency, and Village Community Empowerment.

\begin{abstract}
Abstrak:
Penelitian ini bertujuan untuk menganalisis pengelolaan dana desa untuk peningkatan pemberdayaan masyarakat desa di Kabupaten Wonosobo. Beberapa desa di Kabupaten Wonosobo dipilih berdasarkan berdasarkan klasifikasi Indeks Desa Membangun, meliputi Desa Krasak, Blederan, Kebrengan, dan Derongisor. Penelitian ini menggunakan metode kualitatif dengan pendekatan deskriptif. Teknik pengumpulan data yang digunakan yaitu wawancara, dokumentasi dan observasi. Wawancara dilakukan terhadap informan dari aparatur desa dan perwakilan masyarakat. Analisis data dilakukan dengan pengumpulan data dari transkripsi wawancara, observasi langsung dan peninjauan dokumen. Hasil penelitian menunjukkan bahwa pengelolaan dana desa yang dilakukan oleh pemerintah desa di Kabupaten Wonosobo telah memperhatikan aspek akuntabilitas dan transparasi. Selain itu, penggunaan dana sudah tepat sasaran untuk pemberdayaan mayarakat. Secara umum pengelolaan dana desa yang baik telah meningkatkan pemberdayaan dan memberikan manfaat bagi masyarakat di berbagai bidang.
\end{abstract}

Kata Kunci: Dana Desa, Akuntabilitas, Transparansi, dan Pemberdayaan Mayarakat Desa.

\section{PENDAHULUAN}

Pembangunan berorientasi desa merupakan langkah strategis pemerintah untuk mewujudkan pembangunan nasional 
(Hulu et al., 2018). Tingkat kemiskinan di perkotaan pada Maret 2018 sebesar 7,26\% sementara di pedesaan 13,20\% (Badan Pusat Statistik, 2018). Kondisi tersebut menunjukkan adanya ketimpangan antara desa dan kota yang mengindikasikan pemberdayaan masyarakat yang belum merata. Oleh karena itu, pemerintah Indonesia berupaya untuk memaksimalkan sumber daya yang ada dengan kebijakan dana desa. Pemberian dana desa diprioritaskan untuk pembangunan infrastruktur dan pemberdayaan masyarakat (Hulu et al., 2018). UU Nomor 6 tahun 2014 memberikan peluang desa untuk meningkatkan pemberdayaan masyarakat (State Secretariat, 2014). Tujuan penelitian ini adalah menganalisis akuntabilitas dan transparansi pengelolaan dana desa untuk pemberdayaan masyarakat di Kabupaten Wonosobo.

Pemberdayaan masyarakat merupakan upaya untuk menciptakan kemandirian pengelolaan potensi yang dimiliki masyarakat (Hadiyanti, 2008). Pemberdayaan masyarakat desa yang optimal meningkatkan kapasitas masyarakat desa dalam peningkatan wirausaha, peningkatan pendapatan, dan perluasan skala ekonomi masyarakat desa (Sofianto, 2017), sehingga penting dikelola untuk mengatasi permasalahan kemiskinan. Meskipun dana desa dapat meningkatkan aksesbilitas dan partisipasi masyarakat dalam upaya pembangunan dan pemberdayaan masyarakat, baik dalam segi ekonomi, politik, dan sosial masyarakat (Sofianto, 2017), tetapi pengelolaan dana desa perlu diimbangi dengan akuntabilitas dan transparansi (Arifiyanto \& Kurrohman, 2014) agar penggunaannya tepat sasaran dan optimal.

Dana desa menjadi salah satu faktor yang berkontribusi dalam peningkatan status desa dan pengurangan angka kemiskinan desa (Kementerian Desa Pembangunan Daerah Tertinggal dan Transmigrasi Republik Indonesia (Kemdes PDTT RI). Kemdes PDTT RI berhasil meningkatkan status desa dari desa berkembang menjadi desa mandiri pada tahun 2014-2019 serta mengentaskan ketertinggalan sumber pemasukan dan taraf hidup masyarakat sekitar 5.000 desa. Selain itu, pengalokasian dana desa dari Anggaran Pendapatan dan Belanja Negara (APBN) pada tahun 2015 hingga 2017 mengalami kenaikan, yakni rata-rata Rp 280 juta setiap desa pada tahun 2015 hingga Rp 800 juta setiap desa pada tahun 2017 (Menteri Keuangan Republik Indonesia, 2017). Dana desa yang diprioritaskan untuk pemberdayaan masyarakat juga mengalami kenaikan sebesar Rp 1,8 T dari tahun 2015 ke tahun 2016. Tren ini menunjukkan tingginya komitmen pemerintah untuk memaksimalkan pemberdayaan dan kesejahteraan masyarakat melalui pengelolaan keuangan desa.

Terdapat beberapa hal yang perlu diperhatikan tentang alokasi dana desa dan penyerahan kewenangan pengelolaan keuangan desa kepada pemerintah desa, salah satunya adalah adanya penyimpangan pengelolaan keuangan akibat kurangnya pembinaan bagi aparatur pemerintah desa (Azhari, 2016). Indonesia Corruption Watch (ICW) menunjukkan bahwa pada tahun 2015-2017 dana desa merupakan salah satu penyumbang korupsi terbesar. Berdasarkan hasil pemantauan, tercatat terdapat 17 kasus pada tahun 2015, 42 kasus pada tahun 2016 dan terus meningkat hingga 96 kasus korupsi anggaran desa pada tahun 2017 (Indonesia Corruption Watch, 2018). Nuha et al., (2017) menambahkan bahwa pengelolaan keuangan desa menghadapi tantangan dari aspek kemampuan sumber daya manusia, pengawasan, dan keterbatasan regulasi. Kondisi ini menunjukkan adanya peluang dan tantangan bagi desa untuk mengelola dana tersebut demi mewujudkan pemberdayaan masyarakat desa yang optimal.

Pencegahan kecurangan atau penyelewengan dana dapat dilakukan dengan meningkatkan kualitas tata kelola pemerintahan yang baik (Good Governance). Good Governance untuk mengawasi serta menjamin dana desa yang agar dapat dikelola baik dan memberikan nilai tambah dalam penggunaannya (Sofyani et al., 2018). Pemerintah telah mengatur tentang pengelolaan keuangan desa yang baik melalui Permendagri No. 20 tahun 2018, bahwa pengelolaan keuangan desa didasarkan pada asas transparan, akuntabel, 
partisipatif, serta dilakukan dengan tertib dan disiplin anggaran (Peraturan Menteri Dalam Negeri, 2020). Oleh karena itu, untuk mewujudkan good governance dapat dilakukan dengan menciptakan transparansi dan akuntabilitas dalam pengelolaan keuangan desa (Astuti, 2015).

Akuntabilitas merupakan bentuk tanggungjawab suatu organisasi atau badan untuk mencapai suatu target atau tujuan yang telah ditetapkan yang dilakukan secara berkala (Nafidah \& Suryaningtyas, 2016), sementara transparansi merupakan konsep yang terkait dengan ketersediaan informasi dan akses serta kegunaan sebuah informasi oleh warga negara dan pemangku kepentingan (Araujo \& Tejedo-Romero, 2016). Melalui transparansi, masyarakat desa dapat turut serta dalam mengawal pengelolaan dana desa guna mencegah adanya penyelewengan anggaran atau wewenang (Ferarow \& Suprihanto, 2018). Kedua konsep tersebut sejalan dengan stewardship theory yang merepresentasikan pertanggungjawaban pribadi dalam bekerja untuk mencapai kesejahteraan masyarakat dengan menjaga kewajiban dan komitmen kepada masyarakat (Jefri, 2018).

Wonosobo dinilai memiliki potensi untuk diteliti berdasarkan klasifikasi Indeks Desa Membangun, yaitu memiliki desa dengan kategori desa mandiri, desa maju, desa berkembang dan desa tertinggal. Wonosobo juga merupakan wilayah dengan dana desa yang mengalami peningkatan 3 tahun berturut-turut pada 2015-2017. Alokasi dana ini perlu diimbangi dengan pengelolaan dana desa yang sesuai prosedur. Penelitian sebelumnya telah menguji tingkat transparansi dan akuntabilitas pengelolaan keuangan desa di Wonosobo dengan metode survey (Ngakil \& Kaukab, 2020), pengawasan penggunaan dana (Sagita \& Widayati, 2017) dan kontribusi partisipasi masyarakat (Kartika, 2012). Penelitian ini memberikan kontribusi dengan menggunakan perspektif kualitatif untuk menganalisis secara eksploratif tentang penerapan akuntabilitas dan transparansi pengelolaan keuangan desa. Selain itu, penelitian ini juga fokus pada prioritas dana desa untuk tujuan pemberdayaan masyarakat, sehingga akan diperoleh gambaran penerapan akuntabilitas dan transparansi dari sisi pemangku kepentingan dan pemerintah desa.

\section{METODE PENELITIAN}

Penelitian ini merupakan penelitian kualitatif deskriptif untuk menganalisis akuntabilitas dan transparansi pengelolaan keuangan desa khususnya dalam meningkatkan pemberdayaan masyarakat. Objek dari penelitian ini adalah empat desa yang berada di Kabupaten Wonosobo yaitu Desa Krasak, Desa Blederan, Desa Kebrengan dan Desa Derongisor. Desa-desa tersebut masing-masing mewakili kategori desa berdasarkan Indeks Desa Membangun (IDM) pada tahun 2019, terdiri dari desa mandiri, maju, berkembang, dan tertinggal. Indeks Desa Membangun (IDM) 2019 tentang Status Kemajuan dan Kemandirian Desa, sebagai berikut:

a. Desa mandiri atau desa swasembada adalah desa yang memiliki Indeks Desa Membangun (IDM) lebih besar (>) 0,8155.

b. Desa maju atau desa pra-sembada adalah desa yang memiliki Indeks Desa Membangun (IDM) kurang dari sama dengan ( $\leq$ ) 0,8155 dan lebih besar (>) dari 0,707 .

c. Desa berkembang atau desa madya adalah desa yang memiliki Indeks Desa Membangun (IDM) kurang dan sama dengan ( $\leq$ ) 0,7072 dan lebih besar (>) dari 0,5989 .

d. Desa tertinggal atau desa pra-madya adalah desa yang memiliki Indeks Desa Membangun (IDM) kurang dan sama dengan ( $\leq$ ) 0,5989 dan lebih besar (>) dari 0,4097 . 
e. Desa sangat tertinggal atau desa pratama adalah desa yang memiliki Indeks Desa Membangun (IDM) kurang dan sama dengan ( $\leq$ ) dari 0,4907.

Informan dalam penelitian ini adalah aparatur pemerintah desa, yaitu Kepala Desa, Sekretaris Desa, Bendahara Desa, dan Badan Permusyawarahan Desa. Selain itu, penelitian melibatkan perwakilan atau tokoh masyarakat desa untuk mengonfirmasi kesesuaian program pemberdayaan masyarakat yang dilakukan oleh pemerintah dengan kebutuhan masyarakat dan manfaat yang dirasakan oleh masyarakat. Informasi dari perwakilan atau tokoh masyarakat ini digunakan untuk menjaga keseimbangan perspektif dan menekan kemungkinan bias normatif pada hasil penelitian (Sofyani et al., 2018).

Penelitian ini menggunakan data primer, dengan teknik pengumpulan data berupa wawancara, observasi, dan dokumentasi. Wawancara dilakukan dengan informan penelitian dari sisi pemerintah desa dan masyarakat. Sumber data observasi diperoleh melalui pengamatan langsung terhadap kondisi lapangan objek penelitian. Dokumentasi dilakukan dengan penelusuran terhadap dokumen pendukung terkait akuntabilitas dan transparansi pelaporan keuangan desa.

Analisis data dalam penelitian kualitatif erat kaitannya dengan proses pengumpulan data, yaitu bahwa analisis data dilakukan bersamaan dengan proses pengumpulan data, menginterpretasi data hingga membuat laporan (Creswell, 2009). Rekaman wawancara ditranskripkan menjadi teks dan dilengkapi catatan lapangan hasil observasi langsung. Data tersebut ditinjau secara berkala untuk dapat memahami informasi yang disampaikan oleh informan secara komprehensif. Selain itu, data berupa hasil observasi lapangan dan dokumen digunakan untuk menguatkan informasi yang diperoleh dari hasil wawancara.

Peneliti melakukan beberapa prosedur untuk menjaga reliabilitas dan validitas data penelitian sebagaimana yang disarankan oleh (Creswell, 2009). Dalam rangka memastikan reliabilitas data hasil wawancara, peneliti melakukan beberapa kali pemeriksaan transkrip wawancara untuk memastikan bahwa tidak ada kesalahan transkripsi yang dapat menyebabkan kesalahan informasi (Creswell, 2009). Sementara untuk meningkatkan validitas data, peneliti melakukan triangulasi dengan menggunakan sumber informasi yang berbeda, yaitu dengan menggunakan dua perspektif pemerintah desa dan masyarakat untuk menambah validitas penelitian. Selain itu peneliti juga mendukung informasi tersebut dengan data observasi dan juga dokumen pendukung.

\section{HASIL DAN PEMBAHASAN}

Sehubungan dengan teknik penelitian yang digunakan pada penelitian ini adalah wawancara, berikut merupakan daftar informan beserta kodifikasi untuk membantu pembahasan pada hasil penelitian ini. Secara singkat penelitian ini mengumpulkan data dari informan masing-masing satu Kepala Desa, satu Sekretaris Desa, satu Bendahara Desa, satu perwakilan BPD dan satu perwakilan dari tokoh masyarakat per Desa yang menjadi sampel dari Kabupaten Wonosobo, yaitu Desa Krasak, Desa Blederan, Desa Kebrengan, dan Desa Derongisor.

\section{Profil Desa}

\section{Desa Krasak}

Desa Krasak merupakan desa yang terletak di Kecamatan Mojotengah, Kabupaten Wonosobo. Desa ini termasuk dalam kategori desa mandiri berdasarkan IDM (Indeks Desa Membangun) 2019 . Adapun mayoritas mata pencaharian warga yaitu pedagang, panai besi, dan wiraswasta. Mayoritas warga memiliki tingkat pendidikan hingga bangku SMP dan SMA/Sederajat 


\section{Desa Blederan}

Desa Blederan merupakan salah satu di Kabupaten Wonosobo yang terletak di sisi paling utara wilayah Kecamatan Mojotengah dan berbatasan langsung dengan wilayah Kecamatan Garung, yaitu disebeah utara Desa Sendangsari (Kecamatan Garung), disebelah timur Desa Gemblengan (Kecamatan Garung), disebelah selatan Desa Bumirejo (Kecamatan Mojotengah), dan disebelah barat Desa Wonokromo (Kecamatan Mojotengah). Desa Blederan termasuk dalam kategori desa maju berdasarkan IDM (Indeks Desa Membangun) 2019. Mayoritas masyarakat di Desa Blederan berprofesi sebagai petani dan pedagang.

\section{Desa Kebrengan}

Desa Kebrengan merupakan desa yang terletak di Kecamatan Mojotengah, Kabupaten Wonosobo. Desa Kebrengan merupakan salah satu desa yang termasuk dalam kategori desa berkembang berdasarkan IDM (Indeks Desa Membangun) 2019. Mata pencaharian masyarakat Desa Kebrengan sebagian besar adalah petani, dengan wilayah yang didominasi oleh lahan pertanian.

\section{Desa Derongisor}

Desa Derongisor merupakan desa yang terletak di bagian barat laut Kabupaten Wonosobo yang berbatasan langsung dengan Desa Deroduwur di bagian utara, Desa Wonokromo di bagian timur, Desa Mojosari di bagian selatan, dan Desa Lumajang (Kecamatan Watumalang) dibagian Barat. Selain itu, Desa Derongisor merupakan salah satu desa yang termasuk dalam kategori desa tertinggal berdasarkan IDM (Indeks Desa Membangun) 2019. Sebagian besar mata pencaharian warga sebagai petani seperti padi atau sayur-sayuran, dapat dilihat dari kondisi wilayah geografis Desa Derongisor yang sebagian besar merupakan tanah olahan.

Tabel 1. Deskripsi Dan Kodifikasi Informan Penelitian

\begin{tabular}{cccc}
\hline No & Desa & Posisi & Kode \\
\hline 1 & Krasak1 & Kepala Desa & KR1 \\
2 & Krasak2 & Sekretaris Desa & KR2 \\
3 & Krasak3 & Bendahara Desa & KR3 \\
4 & Krasak4 & BPD Krasak & KR4 \\
5 & Krasak5 & Tokoh masyarakat & KR5 \\
6 & Blederan1 & Kepala desa & BL1 \\
7 & Blederan2 & Sekretaris Desa & BL2 \\
8 & Blederan3 & Bendahara desa & BL3 \\
9 & Blederan4 & BPD Blederan & BL4 \\
10 & Blederan5 & Tokoh masyarakat & BL5 \\
11 & Kebrengan1 & Kepala Desa & KBR1 \\
12 & Kebrengan2 & Sekretaris Desa & KBR2 \\
13 & Kebrengan3 & Bendahara desa & KBR3 \\
14 & Kebrengan4 & BPD Kebrengan & KBR4 \\
15 & Kebrengan5 & Tokoh masyarakat & KBR5 \\
16 & Derongisor1 & Kepala Desa & DRS1 \\
17 & Derongisor2 & Sekretaris Desa & DRS2 \\
18 & Derongisor3 & Bendahara Desa & DRS3 \\
19 & Derongisor4 & BPD Derongisor & DRS4 \\
20 & Derongisor5 & Tokoh masyarakat & DRS5 \\
\hline Sumber $:$ Data penelitian (2020) & &
\end{tabular}

Sumber: Data penelitian (2020)

Dana Desa merupakan dana yang diterima oleh setiap desa yang bersumber dari APBN atau Pemerintah Pusat. Penggunaan dana desa didasarkan pada peraturan yang telah ditetapkan oleh pemerintah. Berdasarkan Peraturan Pemerintah No. 60 Tahun 2014 tentang 
Dana Desa, Dana Desa diprioritaskan untuk membiayai pembangunan dan pemberdayaan masyarakat (Presiden Republik Indonesia, 2014). Berdasarkan hasil wawancara yang dilakukan peneliti, secara garis besar akuntabilitas dan transparansi telah dilakukan pada pengelolaan Dana Desa di Desa Krasak, Desa Blederan, Desa Kebrengan, dan Desa Derongisor, sebagai berikut :

Tabel 2. Hasil Penelitian Tentang Akuntabilitas dan Transparansi Pengelolaan Dana Desa

\begin{tabular}{|c|c|c|c|c|}
\hline Keterangan & Desa Krasak & Desa Blederan & Desa Kebrengan & Desa Derongisor \\
\hline Akuntabilitas & $\begin{array}{l}\text { Pembuatan } \\
\text { laporan-laporan } \\
\text { terkait penggunaan } \\
\text { dan pengelolaan } \\
\text { dana desa (SPJ } \\
\text { bulanan, } \quad \text { SPJ } \\
\text { Tahunan, Laporan } \\
\text { Realiasasi APBDes } \\
\text { persemester, } \\
\text { Laporan Realisasi } \\
\text { APBDes satu } \\
\text { tahun, Laporan } \\
\text { Capaian Output, } \\
\text { LPPD, LKPD, dsb). }\end{array}$ & $\begin{array}{lr}\text { Pembuatan laporan- } \\
\text { laporan terkait } \\
\text { penggunaan dan } \\
\text { pengelolaan dana } \\
\text { desa (SPJ bulanan, } \\
\text { SPJ Tahunan, } \\
\text { Laporan Realiasasi } \\
\text { APBDes } \\
\text { persemester, } \\
\text { Laporan Realisasi } \\
\text { APBDes satu tahun, } \\
\text { Laporan Capaian } \\
\text { Output, LPPD, } \\
\text { LKPD, dsb). }\end{array}$ & $\begin{array}{l}\text { Pembuatan } \\
\text { laporan-laporan } \\
\text { terkait penggunaan } \\
\text { dan pengelolaan } \\
\text { dana desa (SPJ } \\
\text { bulanan, } \\
\text { Tahunan, Laporan } \\
\text { Realiasasi APBDes } \\
\text { persemester, } \\
\text { Laporan Realisasi } \\
\text { APBDes } \\
\text { tahun, Laporan } \\
\text { Capaian Output, } \\
\text { LPPD, LKPD, } \\
\text { dsb). }\end{array}$ & $\begin{array}{l}\text { Pembuatan laporan- } \\
\text { laporan terkait } \\
\text { penggunaan dan } \\
\text { pengelolaan dana } \\
\text { desa (SPJ bulanan, } \\
\text { SPJ Tahunan, } \\
\text { Laporan Realiasasi } \\
\text { APBDes } \\
\text { persemester, } \\
\text { Laporan Realisasi } \\
\text { APBDes satu tahun, } \\
\text { Laporan Capaian } \\
\text { Output, LPPD, } \\
\text { LKPD, dsb). }\end{array}$ \\
\hline Transparansi & $\begin{array}{l}\text { Melibatkan seluruh } \\
\text { komponen } \\
\text { masyarakat dalam } \\
\text { penggunaan dana } \\
\text { desa, seperti } \\
\text { musyawarah dalam } \\
\text { menentukkan dari } \\
\text { prioritas dana } \\
\text { penggunaan } \\
\text { desa. } \\
\text { Sarana Informasi: } \\
\text { a. Pemasangan } \\
\text { banner atau } \\
\text { papan infografis. } \\
\text { b. Media Sosial. } \\
\text { c. Website Desa } \\
\text { "PEMDES } \\
\text { KRASAK". } \\
\text { d. Website "OPEN } \\
\text { DATA" dan } \\
\text { "SIDESA } \\
\text { JATENG". } \\
\text { e. Musyawarah. }\end{array}$ & 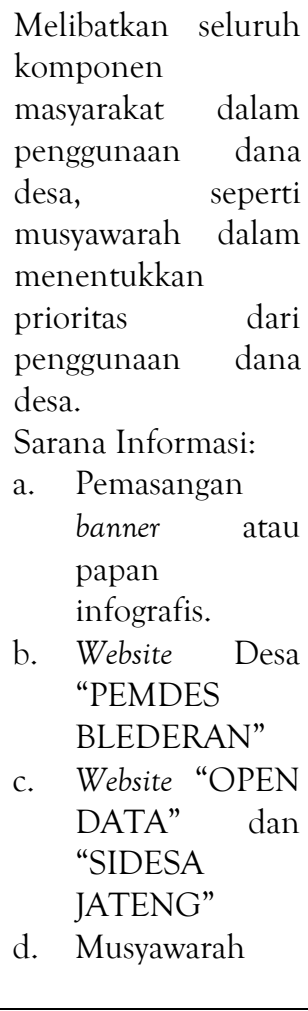 & $\begin{array}{l}\text { Melibatkan } \\
\text { seluruh komponen } \\
\text { masyarakat dalam } \\
\text { penggunaan dana } \\
\text { desa, seperti } \\
\text { musyawarah dalam } \\
\text { menentukkan } \\
\text { prioritas dari } \\
\text { penggunaan dana } \\
\text { desa. } \\
\text { Sarana Informasi: } \\
\text { a. Pemasangan } \\
\text { banner atau } \\
\text { papan } \\
\text { infografis } \\
\text { b. Prasati atau } \\
\text { papan } \\
\text { kegiatan } \\
\text { c. Website } \\
\text { "OPEN } \\
\text { DATA" } \\
\text { d. Musyawarah }\end{array}$ & $\begin{array}{l}\text { Melibatkan seluruh } \\
\text { komponen } \\
\text { masyarakat dalam } \\
\text { penggunaan dana } \\
\text { desa, seperti } \\
\text { musyawarah dalam } \\
\text { menentukkan } \\
\text { prioritas dari } \\
\text { penggunaan dana } \\
\text { desa. } \\
\text { Sarana Informasi: } \\
\text { a. Pemasangan } \\
\text { banner atau papan } \\
\text { infografis } \\
\text { b. Media sosial } \\
\text { c. Kalender memuat } \\
\text { laporan keuangan } \\
\text { desa }\end{array}$ \\
\hline
\end{tabular}

Dalam menetapkan prioritas penggunaan Dana Desa untuk pemberdayaan masyarakat, pemerintah desa melalui beberapa proses hingga prioritas Dana Desa dapat disepakati oleh semua pihak. Berdasarkan hasil wawancara kepada informan meliputi kepala desa, empat sekretaris desa, empat bendahara desa, empat Badan Permusyawarahan Desa (BPD), dan empat tokoh atau perwakilan masyarakat, keempat desa tidak jauh berbeda dalam proses penetapan prioritas dana desa, yaitu dengan mengadakan musyawarah yang melibatkan seluruh elemen masyarakat untuk menampung 
usulan-usulan tentang kebutuhan masyarakat desa untuk selanjutnya diputuskan prioritas alokasinya.

\begin{abstract}
"Kalau di Desa Krasak sesuai dengan Peraturan Perundang-undangan, jadi proses dana desa muncul dari musyawarah kelompok yang terdiri dari masyarakat yang nanti akan lanjut ke musyawarah RT hingga musyawarah RW yang akan menghasilkan berbagai usulan. Usulan yang pertama dibuat digunakan untuk RPJM Desa (Recana Pembangunan Jangka Menengah), sehingga usulan dari masyarakat tentang pemberdayaan, pembangunan atau apapun akan dimasukkan ke RPJM Desa (Recana Pembangunan Jangka Menengah) setiap 6 tahun sekali pada 2020-2025. Setelah itu di setiap tahunnya ada Penyusunan RKP Desa (Rencana Kerja Pemerintah Desa) yang dimulai dari musyawarah dusun yang berlanjut pada pertemuan tingkat desa untuk menentukan nilai bobot usulan yang menjadi prioritas program desa. Sedangkan untuk prioritas pada tahun 2020 kita banyak pada pemberdayaan karena Krasak sendiri termasuk dalam kategori desa yang mandiri sehingga untuk infrastruktur sudah tidak begitu banyak, untuk tahun ini pembangunan hanya gedung olahraga, jalan padagang $R W 1$, dan drainase."-KR2
\end{abstract}

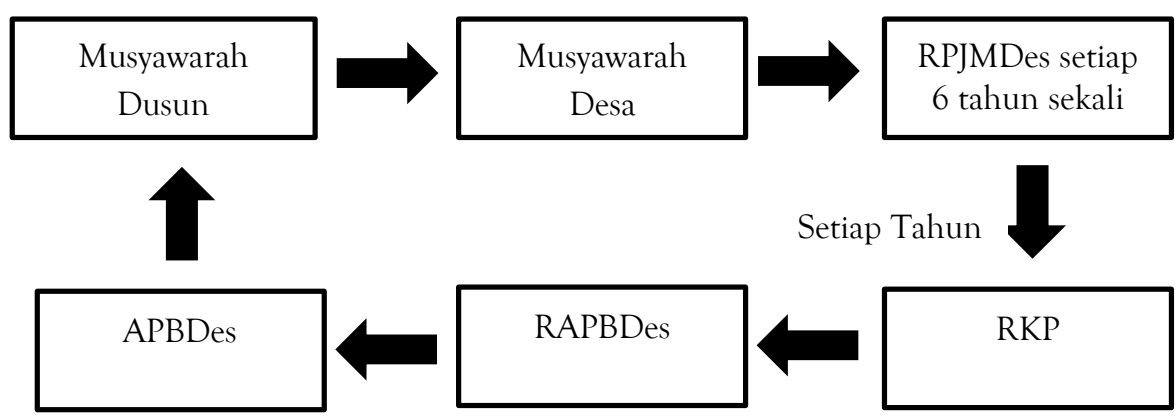

Gambar 1. Proses dalam Menentuan Penggunaan Dana Desa

Musyawarah dimulai dari musyawarah pada tingkat paling kecil, seperti Kelompok/RT/RW yang kemudian dilanjutkan pada Musyawarah Dusun hingga Musyawarah Desa untuk menampung usulan masyarakat. Berdasarkan musyawarah tersebut menghasilkan berbagai usulan yang dinilai berdasarkan skala prioritas yang memang dibutuhkan oleh masyarakat yang dijadikan bahan dalam pembuatan RPJMDes (Rencana Pembangunan Jangka Menengah Desa). RPJMDes disusun setiap enam tahun sekali setiap awal tahun pergantian Kepala Desa. RPJM Des (Rencana Pembangunan Jangka Menengah Desa) tersebut dapat dijadikan dasar dan dijabarkan secara lebih rinci dalam pembuatan RKP (Rencana Kerja Pemerintah) untuk setiap tahunnya. RKP (Rencana Kerja Pemerintah) sendiri juga dijadikan sebagai dasar dalam pembuatan RAPBDes (Rencana Anggaran Pendapatan dan Belanja Desa). RAPBDes (Rencana Anggaran Pendapatan dan Belanja Desa) diusulkanoleh camat kepada bupati, apabila telah disetujui oleh bupati maka pemerintah desa dapat mengesahkan APBDes (Anggaran Pendapatan dan Belanja Desa).

Selain musyawarah, pemerintah desa juga melakukan sosialisasi tentang penggunaan dana desa yang sesuai dengan peraturan kepada masyarakat, sehingga usulan dari masyarakat juga dapat sesuai atau sejalan dengan apa yang diprioritaskan dari pemerintah. Sosialisasi merupakan proses penyampaian kepada kelompok sasaran yang bertujuan untuk membantu kelompok sasaran untuk lebih memahami mengenai suatu hal yang akan diterapkan di masyarakat.

"Pemerintah Desa Krasak telah melakukan sosialisasi terkait dana desa kepada masyarakat melalui banner atau papan infografis dan juga sekarang ada media yang 
dapat diakses oleh masyarakat yang dibuat setiap tahun sebagai salah satu bentuk sosialisasi penggunaan dana desa dari pemerintah desa kepada masyarakat. Sedangkan untuk prioritas penggunaan dana desa di Desa Krasak sendiri untuk tahun ini digunakan untuk pemberdayaan masyarakat."-KR1

"Kalau dana desa untuk sosialisasi lewat papan nama (infografis), untuk intinya kita musyawarah untuk pembuatan APBDes dengan lembaga masyarakat seperti RT/RW dan tokoh masyarakat, karena pembuatan APBDes, penetapan APBDes harus melibatkan partisipasi masyarakat."-KBR1

Pelaksanaan pemberdayaan masyarakat sebagai prioritas dari penggunaan dana desa tentunya dimaksudkan untuk memberikan manfaat kepada masyarakat. Sebagaimana telah dijelaskan dalam Permendesa PDTT No. 11 Tahun 2019, bahwa manfaat prioritas dari penggunaan dana desa adalah peningkatan kualitas hidup, peningkatan kesejahteraan, penanggulangan kemiskinan dan peningkatan pelayanan publik (Menteri Desa, Pembangunan Daerah Tertinggal, 2019). Pemberdayaan masyarakat memberikan berbagai manfaat bagi masyarakat, seperti meningkatkan kualitas atau sumber daya masyarakat, meningkatkan keterampilan masyarakat, membantu perekonomian masyarakat, membuka lapangan pekerjaan, dan mengurangi angka pengangguran.

"Dalam bentuk PKK, terus ada pelatihan untuk petani-petani desa untuk meningkatkan kualitas panen yang dihasilkan, terus kegiatan karang taruna untuk pemuda-pemuda desa. Ya memberikan dampak positif, khususnya bagi mereka yang sebagian besar bermata pencaharian sebagai petani untuk meningkatkan perekonomian, dan untuk karang taruna pemuda juga bisa terhindar dari kegiatan yang negatif. Manfaat dari dana desa untuk membantu perekonomian ya khususnya untuk bantuan polybag, beli bibit, dan lain-lain."-BL5

"Untuk keberhasilan pemberdayaan masyarakat, contohnya untuk tahun 2018 terdapat pelatihan sablon, output-nya walaupun tidak total tetapi persentase keberhasilan tetap ada, terdapat warga yang sudah bisa menyablon. Pelatihan menjahit, komputer juga pasti ada keberhasilannya. Bagi masyarakat, Ketika terdapat program pemberdayaan, masyarakat akan turut merasa diberdayakan, jelas dapat membuka lapangan pekerjaan, kalau imbasnya bagi desa secara data dapat mengurangi anggaran pengangguran."-KR2

Melalui pemberdayaan yang diberikan oleh pemerintah, kini masyarakat dapat membuka usaha sendiri, seperti membuka usaha sablon yang dilakukan oleh masyarakat Desa Krasak dan membuka usaha bidang kuliner di Desa Krebengan dan Derongisor. Selain itu, tidak sedikit masyarakat yang perekonomiannya terbantu melalui hasil dari berbagai pelatihan maupun sosialisasi yang diberikan, seperi di Desa Blederan dengan memberikan pelatihan/penyuluhan tentang pemanfaatan lahan kosong yang dapat ditanami sayursayuran, masyarakat mampu untuk menanam dan memanen sendiri tanaman di lingkungan sekitarnya. Hal tersebut secara tidak langsung dapat membantu mencukupi kebutuhan perekonomian masyarakat. Meskipun tidak semua kegiatan berdampak secara maksimal, namun masyarakat cukup terbantu dan mendapat masukan yang progresif untuk pengembangan dirinya.

Dalam pelaksanaan program pemberdayaan masyarakat dengan dana desa, ada beberapa kendala yang dihadapi oleh aparatur, misalnya aspek sumber daya manusia. Kapabilitas sumber daya manusia sebagai steward maupun sebagai pemangku kepentingan keduanya memerlukan dukungan yang berkelanjutan. Steward dituntut untuk terus 
memperbarui informasi dan meningkatkan kemampuannya sesuai dengan regulasi pemerintah tentang pengelolaan dana desa yang dianggap cukup kompleks. Selain itu, menempatkan masyarakat dalam satu kesempatan yang sama bukanlah hal yang mudah, sehubungan dengan aktifitas masyarakat yang cukup beragam. Beberapa masyarakat juga dianggap masih kurang memahami esensi dari dana desa itu sendiri. Hal tersebut menunjukkan bahwa program tidak akan bisa berjalan secara maksimal meskipun sudah dirancang sedemikian rupa oleh steward, tanpa adanya Kerjasama dan kontribusi dari masyarakat sekitar.

“...., biasanya masyarakat masih awam terkait dana desa."-DRS1

“......Sehingga masyarakat juga diikutsertakan dan bisa mengawasi terkait dana desa, tetapi tidak semua masyarakat peduli terkait dana desa tersebut. Namun, selama ini kami belum menerima aduan yang kurang berkenan dari masyarakat atau tidak sesuai dengan masyarakat. Selain itu, untuk pemerintah desa sendiri sudah sangat terbuka, terlebih BPD harus mengetahui dana bersumber dari mana, dialokasikan kemana. Selanjutnya, masyarakat juga diikutsertakan melalui musyawarah dari tingkat RT, RW, hingga desa. Sementara terkait dana desa sekarang sudah dapat diakses dengan mudah melalui teknologi informasi, hanya saja masyarakat peduli atau tidak itu belum bisa kami kendalikan sepenuhnya."-KR4

Pengelolaan dana desa yang memenuhi akuntabilitas dan transparansi dapat menciptakan good governance, sejalan dengan Pemendagri No.20 Tahun 2018, bahwa dalam melakukan pengelolaan dana desa didasarkan pada asas transparan, akuntabel, partisipatif, serta dilakukan dengan tertib dan disiplin anggaran (Peraturan Menteri Dalam Negeri, 2018). Stewardship theory menyatakan bahwa pemerintah sebagai steward merupakan pihak yang bertanggungjawab untuk menyampaikan pelaporannya kepada masyarakat sesuai porsi dan ketentuan yang berlaku guna memenuhi kebutuhan masyarakat (principal) (Alfasadun et al., 2018). Implikasi dari stewardship theory adalah bahwa pemerintah desa sebagai badan yang diberikan kepercayaan oleh masyarakat untuk melakukan tugas dan fungsinya sesuai dengan kepentingan publik yang dapat dipertanggungjawabkan, seperti pertanggungjawaban laporan keuangan. Dalam hal ini pemerintah merupakan pihak yang memiliki banyak kepercayaan yang telah diberikan oleh masyakat untuk dapat terus mewujudkan akuntabilitas dan transparansi (Khasanah \& Rahardjo, 2014).

Secara umum, setiap desa dalam objek penelitian ini berusaha untuk mengimplementasikan akuntabilitas dalam pelaporan pengelolaan dana desanya. Sementara untuk aspek transparansi, setiap desa cenderung memiliki cara tersendiri dengan memanfaatkan berbagai media informasi yang potensial bagi masyarakat supaya dapat dengan mudah mengakses informasi dana desa. Kedua komponen tersebut telah diperhatikan dengan baik oleh pengelola dana desa, bahwa pemerintah telah memiliki kesadaran dan memahami pentingnya akuntabilitas dan transparansi terhadap principal berkaitan dengan pengelolaan dana desa.

"Berusaha seakuntabel mungkin. Kita biasanya ada SPJ setiap bulan sekali kita setor ke kecamatan, karena setiap selesai melakukan kegiatan kita harus ada SPJ, foto pelaksanaan kegiatan. Pertanggungjawaban kepada masyarakat kita biasanya ada acara setiap tahun yaitu merdi desa, di acara tersebut nanti akan disampaikan oleh kepala desa kepada warga mengenai penggunaan dana desa. Selain itu, juga kita sampaikan pada setiap rapat yang juga dihadiri oleh BPD juga."-KBR3 
"Akuntabilitas sudah jelas melalui papan informasi di tempat strategis, terus untuk tahun ini sedang mengadakan kalender untuk warga yang didalamnya terdapat laporan anggaran dana desa. Kalau laporan seperti SPJ Bulanan, tahunan, dan lainnya. Penyampaiannya biasanya melalui musyawarah desa di akhir tahun"-DRS1

Berdasarkan wawancara dengan informan penelitian, dapat disimpulkan bahwa pemerintah desa mewujudkan akuntabilitas dan transaparansi pelaporan keuangannya dalam berbagai bentuk. Salah satu cara yang digunakan adalah melalui pemasangan papan kegiatan dan prasasti. Papan kegiatan atau prasasti tersebut akan bertuliskan nama kegitaan yang sedang dilaksanakan, besarnya dana yang dipakai, serta asal sumber dana yang digunakan. Selain itu, masing-masing desa telah melakukan pengelolaan sesuai dengan peraturan yang ada, terlihat pemerintah desa melibatkan seluruh elemen, mulai dari BPD, lembaga masyarakat, dan masyarakat untuk bersama-sama dalam mengelola dana desa. Dalam hal pelaporan, pemerintah desa juga telah memperhatikanlaporan-laporan terkait dana desa seperti SPJ setiap bulan, Laporan Realisasi APBDes persemester, Laporan Realisasi APBDes satu tahun, Laporan Capaian Output, LPPD (Laporan Penyelenggaraan Pemerintah Desa), LKPD (Laporan Keuangan Pemerintah Desa), dan sebagainya. Laporanlaporan tersebut dapat disampaikan kepada masyarakat sebagai bentuk pertanggungjawaban pemerintah desa melalui pertemuan-pertemuan warga, seperti musyawarah dusun atau desa, atau dalam kegiatan rutin desa seperti Merdi Desa setahun sekali dan Selapanan yang dilakukan setiap 35 hari sekali.

Pemerintah desa Desa Krasak, Desa Blederan, Desa Kebrengan, dan Desa Derongisor telah berupaya untuk melibatkan masyarakat dalam pengelolaan dana desa untuk menciptakan transaparansi. Masyarakat dengan mudah mengakses informasi yang dibutuhkan melalui papan infografis, kalender, dan teknologi informasi seperti sosial media, website Open Data Desa, website Desa, dan website Provinsi Jateng. Dengan kemajuan tekonologi saat ini bukan hanya masyarakat desa tersebut yang dapat mengakses informasi terkait laporan-laporan dana desa, tetapi semua masyarakat dapat mengaksesnya melalui berbagai media informasi seperti website desa.

\section{KESIMPULAN}

Penelitian ini menemukan bahwa pemerintah Desa Krasak, Desa Blederan, Desa Kebrengan, dan Desa Derongisor telah menunjukkan akuntabilitas dan transparansi dalam pengelolaan dana desa. Pemerintah berkomitmen untuk melibatkan elemen masyarakat sebagai pemangku kepentingan dalam setiap tahapan terkait dana desa. Penggunaan dana desa dialokasikan sesuai dengan fungsi dan prioritasnya untuk kesejahteraan masyarakat dalam rangka pembangunan nasional. Secara keseluruhan, program yang dilaksanakan dengan dana desa khususnya untuk tujuan pemberdayaan masyarakat dapat dirasakan manfaatnya dan meningkatkan kualitas hidup masyarakat. Hal tersebut dapat terwujud dengan cara pertanggungjawaban pemerintah desa terhadap dana yang dikelola. Akuntabilitas dan transparansi merupakan konsekuensi pemerintah atas apa yang telah direncanakan sebelumnya yang menunjukkan bahwa dana desa telah digunakan sebagaimana semestinya, dalam bentuk kelengkapan dokumen pengelolaan dana desa, penyampaian kepada BPD dan masyarakat, media atau sarana untuk mengakses informasi keuangan desa mulai dari papan infografis hingga website yang mempermudah masyarakat memperoleh informasi tentang dana desa.

Implikasi temuan ini penting bagi pemerintah desa untuk mengedepankan tata kelola yang baik, khususnya akuntabilitas dan transparasi untuk kemajuan desa. Tata kelola yang baik mampu meningkatkan pemberdayaan masyarakat yang berdampak pada aspek 
politik, sosial, dan ekonomi. Penting bagi desa untuk terus mengembangan teknologi informasi dalam mendukung semakin transparannya informasi desa. penelitian selanjutnya agar bisa mengeksplorasi potensi dari elemen indeks desa yang terefleksi dalam pengelolaan dana. Selain itu, akan lebih baik apabila dalam proses analisis mengkaji struktur sosial masyarakat karena desa memiliki karakter yang unik.

\section{DAFTAR PUSTAKA}

Alfasadun, Hardiningsih, P., Ratnasari, sri devi, \& Srimindarti, C. (2018). Transparansi dan akuntabilitas pengelolaan dana desa. Prosiding, 2017, 978-979.

Araujo, J. F. F. E. de, \& Tejedo-Romero, F. (2016). Local government transparency index: determinants of municipalities' rankings. International Journal of Public Sector Management, 29(4), 327-347. https://doi.org/10.1108/IJPSM-11-2015-0199.

Arifiyanto, D. F., \& Kurrohman, T. (2014). Akuntabilitas pengelolaan alokasi dana desa di kabupaten jember. Jurnal Riset Akuntansi Dan Keuangan, 2(3), 473-485.

Astuti, T. P. dan Y. (2015). Good Governance Pengelolaan Keuangan Desa Menyongsong Berlakunya Undang-Undang Nomor .6 Tahun 2014. Universitas Setia Budi Surakarta., 1(6), $1-14$

Azhari. (2016). Akuntabilitas Pengelolaan Keuangan Desa Dalam Pemberdayaan Masyarakat (Studi Tentang Peranan Badan Pemberdayaan Masyarakat, Pemerintah Desa, Perempuan dan Keluarga Berencana di Kecamatan Selat Nasik Kabupaten Belitung). Journal Administrative Reform, 4(2), 137-152.

Badan Pusat Statistik. (2018). Profil kemiskinan di indonesia september 2018. Berita Resmi Statistik, 01(05), 1-8.

Creswell, J. W. (2009). Research design: qualitative, quantitative and mixed methods approaches (Third Edit). Sage Publication. https://doi.org/10.2307/1523157.

Ferarow, N., \& Suprihanto, J. (2018). Implementasi pengelolaan keuangan desa sumberadi dan tlogoadi di kabupaten sleman: evaluasi praktik transparansi dan akuntabilitas. Jati: Jurnal Akuntansi Terapan Indonesia, 1(2), 64-69. https://doi.org/10.18196/jati.010207.

Hadiyanti, P. (2008). Strategi pemberdayaan masyarakat melalui pprogram keterampilan produktif di pkbm rawasari, jakarta timur. Perspektif Ilmu Pendidikan, 17(IX), 90-99. https://doi.org/10.21009/pip.171.10.

Hulu, Y., Harahap, R. H., \& Nasutian, M. A. (2018). Pengelolaan dana desa dalam pemberdayaan masyarakat desa. Jupiis: Jurnal Pendidikan Ilmu-Ilmu Sosial, 10(1), 146. https://doi.org/10.24114/jupiis.v10i1.9974

Indonesia Corruption Watch. (2018). Outlook Dana Desa 2018: Potensi Penyalahgunaan Anggaran Desa di Tahun Politik. 6.

Jefri, R. (2018). Teori stewardship dan good governance. Jurnal Riset Edisi XXVI, 4(3), 14-28.

Kartika, R. (2012). Partisipasi masyarakat dalam mengelola alokasi dana desa (ADD) di desa tegeswetan dan desa jangkrikan kecamatan kepil kabupaten wonosobo. Jurnal Bina Praja, 04(03), 179-188. https://doi.org/10.21787/jbp.04.2012.179-188.

Khasanah, N. L., \& Rahardjo, S. N. (2014). Pengaruh Karakteristik, Kompleksitas, Dan Temuan Audit Terhadap Tingkat Pengungkapan Laporan Keuangan Pemerintah Daerah. 3(2), 864-874.

Menteri Desa, Pembangunan Daerah Tertinggal, dam T. R. I. (2019). Peraturan Menteri Desa, Pembangunan Daerah Tertinggal, Dan Transmigrasi Republik Indonesia Nomor 11 Tahun 2019 Tentang Prioritas Penggunaan Dana Desa Tahun 2020. Menteri Desa, Pembangunan Daerah Tertinggal, Dam Transmigrasi Republik Indonesia, 53(9), 1689-1699. https://doi.org/10.1017/CBO9781107415324.004.

Menteri Keuangan Republik Indonesia. (2017). Buku Saku Dana Desa.

Nafidah, L. N., \& Suryaningtyas, M. (2016). Akuntabilitas pengelolaan alokasi dana desa dalam 
upaya meningkatkan pembangunan dan pemberdayaan masyarakat. BISNIS : Jurnal Bisnis Dan Manajemen Islam, 3(1), 214. https://doi.org/10.21043/bisnis.v3i1.1480.

Ngakil, I., \& Kaukab, M. E. (2020). Transparansi dan akuntabilitas pengelolaan keuangan desa di kabupaten wonosobo. Journal of Economic, Management, Accounting and Technology, 3(2), 92107. https://doi.org/10.32500/jematech.v3i2.1283.

Nuha, S. S., Juliani, H., \& Saadah, N. (2017). Implementasi Peraturan Daerah Nomor 11 Tahun 2014 Tentang Pengelolaan Keuangan Dan Aset Desa Dalam Mewujudkan Pembangunan Desa Pada Desa Punjulharjo Kecamatan Rembang Kabupaten Rembang. Diponegoro Law Journal, 6, 1-22.

Peraturan Menteri Dalam Negeri. (2018). Permendagri no 20 tahun 2018. Permendagri No 20 Tahun 2018 Tentang Pengelolaan Keuangan Desa, Nomor 65(879), 2004-2006.

Presiden Republik Indonesia. (2014). Peraturan Pemerintah Republik Indonesia Nomor 60 Tahun 2014 tentang Dana Desa yang Bersumber Dari Anggaran Pendapatan dan Belanja Negara. Jdih Bpk Ri, 6(11), 951-952. https://peraturan.bpk.go.id/Home/Details/5501.

Sagita, R. A., \& Widayati, W. (2017). Pengawasan penggunaan dana transfer untuk menjamin akuntabilitas pengelolaan keuangan desa di kabupaten wonosobo. Jurnal Hukum Khaira Ummah, 12(2), 293-306. jurnal.unissula.ac.id/index.php/jhku/article/download/1862/1406.

Sofianto, A. (2017). Kontribusi dana desa terhadap pembangunan dan pemberdayaan masyarakat di kebumen dan pekalongan. Matra Pembaruan, 1(1), 23-32. https://doi.org/10.21787/mp.1.1.2017.23-32.

Sofyani, H., Suryanto, R., Arie Wibowo, S., \& Widiastuti, H. (2018). Praktik pengelolaan dan tata kelola pemerintahan desa dlingo di kabupaten bantul: pembelajaran dari desa percontohan. Jati: Jurnal Akuntansi Terapan Indonesia, 1(1), 1-16. https://doi.org/10.18196/jati.010101.

State Secretariat. (2014). Undang Undang Republik Indonesia Nomor 6 Tahun 2014 Tentang Desa. Jurnal Article, 1, 1-103.

http://www.setneg.go.id/index.php?lang=en\&option=com_perundangan\& $\mathrm{id}=404095 \&$ task $=$ detail $\&$ catid=1\&Itemid=42\& tahun=2014. 